\title{
The Politics of Naming: A Personal Reflection ${ }^{1}$
}

\author{
Valerie Alia \\ Leeds Metropolitan University, U.K.
}

\begin{abstract}
Naming is an important key to understanding power relations. My inquiry into what I have called political onomastics-the politics of naming-dates back to the early 1980 s and includes research on the experiences and practices of Inuit and of immigrants in Canadian, U.S., and European diasporas. Having looked at naming across various regions, nations, and cultures, it seemed time to bring the journey closer to home. As the child of European-Jewish immigrants to North America, I grew up hearing naming stories. Here I consider the power of naming, starting at Ellis Island and including experiences of naming in a multicultural family, self re-naming and remarriage, and reflect on the differences and similarities between Ashkenazim and Inuit, homeland and diaspora.
\end{abstract}

"There is no social agent who does not aspire ... to have the power to name and to create the world through naming," wrote the sociologist Pierre Bourdieu (1991, 105). Bourdieu called "official" naming "a symbolic act of imposition [that makes] the state the holder of the monopoly of legitimate symbolic violence" $(1991,239)$.

On the surface, naming is simply part of the process by which people classify their environment, but $I$ have observed that it is much more. Naming people and places is a politically significant, universal activity, which has a crucial impact on power relations within families, communities, regions, and nations. While naming has been studied in various ways, and in a wide range of disciplines, the "politics of naming" has never been adequately defined or studied as such. It has existed between the lines and on the margins of anthropology, linguistics, political science, sociology, cultural studies, and-of course-onomastics. Onomasts are increasingly engaged in considering questions of politics and

Names 55.4 (December 2007): 457-464

ISSN: 0027-7738

(C) 2007 by The American Name Society 
power, though such questions often remain marginal or undefined. It is my contention that naming is inseparable from other political phenomena and is an important key to understanding power relations in a range of settings. I have called this work political onomastics, the politics of naming.

Since the early 1980s, I have sought to move the inquiry forward, with a goal of understanding naming within and across cultures as it embodies, creates, and maintains relations of privilege and power. It is my hope that my research into the archives and experiences of Inuit and of immigrants in Canadian, U.S., and European diasporas will contribute to a better understanding of the role of naming in political behavior and the structures of politics and power.

It is said that one's research interests often derive from personal experiences and concerns. I spent many years studying the naming of countless individuals and cultures before it dawned on me that it might be useful to look closer to home. Placing a closeup lens on my own encounters with naming, I could see why I was so strongly drawn to studying the politics of naming. Here, I temporarily set aside the inquiry into the experiences of others and focus on some of my personal experiences with the power of naming.

\section{Immigrants}

All those names mangled on Ellis Island. . .

. . .cut, stitched, and. . remade as Mann. . .Carpenter or Leary.

... Others, more secretive or radical,

made up new names. . .(Satyamurti 2005, 25)

As a child of European-Jewish (Ashkenazi) immigrants to North America, I grew up hearing naming stories. I knew I was named Valerie for a place called Valeria where my parents met, and Lee to commemorate a relative named Leah. I knew I was a giver as well as a receiver of names when, at age six, my parents invited me to help name my sister. I also knew the limits to my power, as my original choice of Susannah (which I thought fancier and prettier) was shortened to my parents' preference for Susan.

My next name-giving experiences were as a mother. My sons, David and Daniel Restivo (who now call themselves Dave and Dan) were named to commemorate the different families and cultures they inherited 
(Italian-Catholic, Hungarian-Jewish). Dave's middle name, Owen, commemorates a residence hall at Michigan State University, where his parents met. Dan's middle name, Olam, is from a Hebrew word meaning 'world', 'universe', or 'humanity', suggested by our friend, William Benjamin, when we ran out of ideas for another "O" name. The middle "O" that creates my sons' shared monogram (DOR) itself has several private meanings. It is a beautiful and untranslatable word in Romanian, which I was studying when Dave was born. In French, dor means 'of gold'; in Hebrew, 'generation'.

My daughter-in-law, Peggy Jane Hope, shares a name with her mother and maternal grandmother. The naming of my wonderful granddaughter, Mary Margaret, (whose Hebrew name, Zahara, means 'to shine' and who is nicknamed MMZ) is much more complicated. In an account reminiscent of Inuit naming stories, her father recalls how she "named herself" a few days after she was born:

She picked her own name, from a series of names that each of us liked. All the names were written four times and she was given four opportunities to pick randomly. That is the name she picked every single time, and the only name anyone else got when they tried. So I guess she knew who she was! (Restivo 2004)

The name Margaret follows her mother's family custom of giving that name to a girl in each generation. That lovely tradition is in direct conflict with her father's Ashkenazi Jewish heritage, in which it is forbidden to name a child for a living relative. In a multicultural family there is no perfect way to resolve such differences. Even where all members of a family share a cultural background, there are issues. Immigrants often name or rename family members to reflect the language and customs of the new country.

My father's family immigrated to the United States long before he and his siblings were born. Like many others, the family maintained a double cultural life. I knew that my father's "American" name, Julius, was transformed in Hebrew to Yehuda in family conversations and in synagogue.

I knew that for decades he had fooled my mother into thinking his middle name was the dashingly European Anatol instead of the ordinary, if Biblically distinguished, Abraham. He playfully stole his adopted name 
from Arthur Schnitzler's eponymous play recounting the adventures of a spoiled young rake. Along with other Schnitzler works, Anatol (written in 1893) enjoyed New York revivals in the early years of my parents' marriage. They were Schnitzler fans, and my mother thought Anatol a charming "coincidence."

I also knew that my father sometimes used his monogram, JAG, as a nom de plume. I thought it great fun to read a letter from a reader calling him "JAG m'boy" (Graber 1931). On rereading the cuttings of his reviews for the publication of New York's Ninety-second Street $Y$ (the YMHA, or Young Men's Hebrew Association), the Bulletin, I see that this was a response from "The Notorious -O-" to his review of Eugene O'Neill's play, Mourning Becomes Electra, and (based on this and previous correspondence) suspect it was the playwright himself who was responding.

I knew my mother hated her name. At birth she had received a "good name," the Hungarian version of Rebecca. In childhood she was given a nickname meaning 'buddy', which in Hungarian also started with "B." As a small child arriving with her family at Ellis Island, she was crudely renamed by an immigration officer whose sensitivities (if there were any) were likely subsumed by a preoccupation with moving people swiftly through the line. Hearing her Hungarian nickname, that powerful but anonymous individual inscribed the new identity that would follow her on documents throughout her life: Bertha.

It was a name she considered ugly, though she sometimes joked about "Bertha the sewing machine girl," an industrious garment worker in Harold Rome's 1937 Pins and Needles. Rome's musical was derived from an earlier play with roots in a less cheery dime novel called Bertha the Sewing Machine Girl or Death at the Wheel, by Frances S. Smith (1871). In the musical version-inspired and produced by members of the International Ladies' Garment Workers (ILGWU)-Bertha survives the dangers of a lecherous, non-union impostor and is taught how to preserve her virtue in the song, "It's Better with a Union Man:" "Always be upon your guard/Demand to see a union card!" (Bronski 2003). My parents loved the show; my mother continued to dislike her name, both in its original form and in her acquired nickname, Bert. The injury of renaming was compounded by poverty and loss; her mother died of puerperal fever soon after my mother was born. I could never understand 
why she did not change her name back to Rebecca, and reclaim her birthright.

When I left the United States for a new life in Canada, I took a new last name-Alia, a Hebrew and Arabic word meaning 'going up'-to new places (both geographic and sacred) and new levels of consciousness. Having discarded both "maiden" and "married" names for an identity of my own, I vowed never again to change my name for others. I kept that vow even when I joyfully married Pete Steffens, whose father, the great muckraker Lincoln Steffens, was much admired and often quoted in my parents' home (and who, in recent years, has been rediscovered and republished). I love, respect and treasure that name. Nevertheless, I have kept my own.

Pete's real name is Pete, not Peter, though people often get it wrong (including scholars who think that Peter Steffens is a mysterious other man). Pete's father nicknamed his mother Peter (for Peter Pan) and then named him for her, adding the straight-laced middle name, Stanley, in case he grew up wanting to be a businessman or banker. In the Autobiography, Lincoln Steffens explains the naming games:

This girl danced. Her eyes danced, her mind, her hands, her feet danced as she ran. . . . I was fascinated. . . She was not for me, of course. Too young. But I felt something which I smothered by likening her to a boy. Her name was Ella Winter, but I called her Peter.

...

... she had not decided which of her suitors would suit her. . in short, I disapproved of all the other candidates for husband and recommended myself. . . . We went to San Remo, took a villa, and there in the fall of 1924 my son, Pete Stanley Steffens, named after his mother, Peter, was born. $(1931,812,820)$

Ella Winter came from an Ashkenazi Jewish family originally called Wertheimer. Branches of the family immigrating to Britain, Australia, and the United States variously renamed themselves Wertham, Winton, and Winter. Freda Lust and Adolph Wertheimer left Nuremberg for London and then Melbourne, where their children, Rudolph, Rosa, and Eleanora (Ella), were born. Returning to London in 1910, they encountered a climate of anti-German hatred and changed their name to Winter to disguise their German origins. 


\section{Names 55.4 (December 2007)}

From the Wertham branch of the family came the American psychiatrist and author, Fredric Wertham, whose postwar struggle to understand the roots of violence resulted in his 1953 study of the effects of violent comic books on children.

From the Winton branch came the English stockbroker, Nicholas Winton, who in 1939 organized the rescue of 669 children from Nazi-occupied Czechoslovakia (BBC 1998; CNN September 2002; CNN December 2002). From the Winter branch came the Australian-British activist and author, Ella Winter, my husband's mother (Winter 1968; Winter and Shapiro 1962).

An outsider would be hard pressed to trace the family line through all the changes of names and countries. It is reminiscent of a well-known joke. Two immigrants meet. One says "What's your name?" The other tells his name, to which the first person replies by asking "What was it before?"

Pete's daughters were named by their Israeli mother. Daneet is the feminine form of Dan, which in Hebrew means 'judge'. Sivan is an early summer month in the Hebrew calendar, chosen for its sound rather than its meaning, as Sivan was born in January.

\section{Inuit}

Despite the vast cultural and geographical differences between Jewish Europe and North America, and Inuit-dominated Nunavut in the Canadian Arctic, my personal experiences with names and naming provided excellent preparation for my encounters with Inuit and their ways of naming. Like Ashkenazim, Inuit prefer commemorative naming, treasure and honor the namesake connection, and when naming their children, usually choose names of relatives who are no longer living. Like Inuit, Ashkenazim see namesake relationships as a way of continuing people's lives. I have heard stories of survivors naming children for each relative who was killed in the Holocaust, not resting until every name was sent on its new life's journey (see, for example, Epstein 1979; Kaganoff 1977; Stein 1993). However, Inuit have taken the namesake relationship farther, to a sometimes literal version of reincarnation in which the life of the namesake continues through the children who carry the name. 
The parallels and similarities suggest why I may have felt so much at home on landing in a culture and country entirely unfamiliar. Before my first trip to what is now Nunavut I had never been to the Arctic or sub-Arctic, met any Inuit, or learned more than a few words of Inuktitut (the dominant language in Nunavut). Certainly, it was a shock to feel comfortable among people who spoke an unfamiliar language, who lived in a region remote from anywhere I had ever been, and who on the surface had nothing in common with my own ancestry. However, it was not only naming that brought us together. Even when specific comments had to be translated by an interpreter, the Inuit style of humor, laughter and body language often felt like home.

One of the major differences between Inuit experiences and my own was that Inuit had a homeland, formalized in 1999 with the creation of Nunavut in the eastern Canadian Arctic, where Inuit constitute an $85 \%$ majority. My own people had been widely dispersed over generations and centuries. Like Inuit, they had adopted what anthropologist Robert Williamson called "underground naming" practices when culturally or personally threatened by those with greater power. One way they kept their cultures alive was to use traditional names in private, while adopting names more acceptable or accessible to others for use in public contexts such as schools and birth registries. Inuit cultural maintenance took place within the Inuit homeland, in the face of incursions from Euro-Canadian outsiders. Jewish naming evolved outside the homeland, and reflects the struggle to maintain one's own culture in diaspora. Whether in diaspora or homeland, the naming practices and names reveal something of the status, politics, and power in the lived experiences of their owners.

Note

1. This essay is adapted from my book, Names and Nunavut, cited below.

References

Alia, Valerie. 2007. Names and Nunavut: Culture and Identity in Arctic Canada. Oxford and New York, Berghahn Books.

Bourdieu, Pierre. 1991. Language and Symbolic Power. Cambridge, MA: Harvard Univ P.

British Broadcasting Corporation. 1998. "The Jerusalem Report." BBC News, 31 August. 


\section{Names 55.4 (December 2007)}

Bronski, M. 2003. "Love's Labor's Lost: Looking Back at 'Pins and Needles,' the Play that was Union-made." Forward (online version), 11 April.

CNN. 2002. "Honor for British Schindler." CNN News, 26 September. . "British Schindler Gets Knighthood" CNN News, 31 December.

Epstein, Helen. 1979. Children of the Holocaust. New York: Bantam.

Graber, Julius A. ("JAG"). 1931. Review of Mourning Becomes Electra and letter to the reviewer. Bulletin. NY YMHA, no specific date or page number available.

Kaganoff, Benzion C. 1977. A Dictionary of Jewish Names and their History. New York: Schocken.

Restivo, David. 2004. Personal Communication.

Satyamurti, Carole. 2005. "Immigrants." Independent on Sunday, 29 May. P. 25.

Steffens, Lincoln. 1931. The Autobiography of Lincoln Steffens. New York: Harcourt Brace.

Stein, André. 1993. Hidden Children: Forgotten Survivors of the Holocaust. Toronto: Penguin.

Wertham, Fredric. 1953. Seduction of the Innocent. New York: Rinehart. Williamson, Robert. 1974. Eskimo Underground: Socio-Cultural Change in the Canadian Central Arctic. Uppsala: Institutionen förallmen ochjamförand etnografi vid Uppsala Universitet.

Winter, Ella. 1968. And Not to Yield: An Autobiography. New York: Harcourt, Brace \& World.

and H. Shapiro. 1962. The World of Lincoln Steffens. New York: Hill and Wang. 